\title{
Dental bleaching gels do not alter the surface roughness and microhardness of feldspathic porcelain
}

\author{
A rugosidade e a microdureza da superfície de porcelana \\ feldspática não são alteradas pelo clareamento dental
}

\author{
Danyelle Cambraia Franco de SOUZA' iD https://orcid.org/0000-0001-6873-8165 \\ Lisia Aparecida Costa GONÇALVES' ${ }^{\text {iD }}$ https://orcid.org/0000-0002-2879-4055 \\ Kellen Cristina da Silva GASQUE² ID https://orcid.org/0000-0003-2015-2717 \\ Ana Beatriz da Silveira MORETTI ${ }^{1}$ iD https://orcid.org/0000-0002-9953-6010 \\ Bruno Franciel DA SILVA' ID https://orcid.org/0000-0002-4963-5598 \\ Rafael Tobias MORETTI NETO' ${ }^{\text {iD }}$ https://orcid.org/0000-0003-1264-2505
}

\begin{abstract}
Objective: To evaluate whether two different bleaching gels affect the microhardness and surface roughness of feldspathic ceramic specimens, in vitro. Methods: A total of 48 feldspathic porcelain IPS In Line (Ivoclar-Vivadent) discs (16/treatment group) were immersed in distilled water (Group I, Untreated control, UN), or treated with the bleaching gels: Opalescence (15\% carbamide peroxide; OPA) and Opalescence Xtra Boost (38\%hydrogen peroxide; OPAXB), for $1 \mathrm{~h}$ or $6 \mathrm{~h}$ daily for 14 days. Surface roughness (Ra) and microhardness (Knoop, or KNP) measurements were made before and after treatment, and data were subjected to statistical analysis by paired Student's t-test $(p<0.05)$. Results: Treatments using Opalescence and Opalescence Xtra Boost did not altered surface roughness $(p=0.6199861)$ or microhardness $(p=0.14286744)$ of the feldspathic porcelain tested in this study. Conclusion: Bleaching treatments using Opalescence and Opalescence Xtra Boost may be suitable for treatment in patients having ceramic prosthodontic treatment.
\end{abstract}

Indexing terms: Bleaching agents. Dental porcelain. Hardness tests.

\section{RESUMO}

Objetivo: Avaliar se dois géis clareadores diferentes afetam a microdureza e a rugosidade superficial de corpos de prova de cerâmica feldspática, in vitro. Métodos: um total de 48 discos de porcelana feldspática IPS In Line (Ivoclar-Vivadent) (16 / grupo de tratamento) foram imersos em água destilada (Grupo I, Controle não tratado, ONU), ou tratados com os géis clareadores: Opalescence (15 \% peróxido de carbamida; OPA) e Opalescence Xtra Boost (38\% peróxido de hidrogênio; OPAXB), por 1 h ou 6 h diariamente por 14 dias. Medidas de rugosidade superficial (Ra) e microdureza (Knoop, ou KNP) foram regristradas antes e depois do tratamento, e os dados foram submetidos à análise estatística por teste $t$ de Student pareado $(p<0,05)$. Resultados: Os tratamentos com Opalescence e Opalescence Xtra Boost não alteraram a rugosidade superficial ( $p=0,6199861$ ) ou a microdureza $(p=0,14286744)$ da porcelana feldspática testada neste estudo. Conclusão: Os tratamentos clareadores com Opalescence e Opalescence Xtra Boost podem ser adequados para o tratamento de pacientes submetidos ao tratamento com prótese cerâmica.

Termos de indexação: Clareadores. Porcelana dentária. Testes de dureza.

$\nabla \nabla \nabla$

1 Universidade Federal de Alfenas, Faculdade de Odontologia, Programa de Pós-Graduação em Ciências Odontológicas. Rua Gabriel Monteiro da Silva, 700, 37130-000, Alfenas, MG, Brasil. Correspondence to: RT MORETTI NETO. E-mail: <rafael.moretti@unifal-mg.edu.br>.

2 Fundação Oswaldo Cruz, Gerência Regional de Brasília, Secretaria Executiva da UNA-SUS. Brasília, DF, Brasil.

$\boldsymbol{v} \mathbf{v} \boldsymbol{v}$

How to cite this article

Souza DCF, Gonçalves LAC, Gasque KCS, Moretti ABS, Silva BF, Moretti Neto RT, Surface roughness and microhardness. RGO, Rev Gaúch Odontol. 2020;68:e20200049. http://dx.doi.org/10.1590/1981-863720200004920190053 


\section{INTRODUCTION}

Tooth bleaching is an effective and non-invasive aesthetic treatment that has become popular in dentistry, and can be performed either by dentists at dental offices, or by patients themselves at home [1-4]. Depending on the etiology of color and intensity changes, teeth whitening is the treatment of choice to improve smile appearance [4]. As bleaching becomes increasingly popular, concerns on the adverse effects of bleaching agents on the enamel and restorative materials have emerged as a key issue for new research in dentistry. At home, tooth bleaching can be performed by long-term application of an oxidizing agent, such as a hydrogen peroxide or carbamide peroxide, at low concentrations. In contrast, bleaching in dental offices is achieved by the application of a highly concentrated hydrogen peroxide bleaching gel (usually at $35 \%$ ), over short periods [5].

Carbamide peroxide is very unstable and will immediately degrade into hydrogen peroxide and urea, upon contact with tissues and saliva [1,6]. Hydrogen peroxide acts as a strong oxidizing agent, through the formation of free radicals, reactive oxygen molecules, and anions [6]. Thus, the direct contact with bleaching agents may cause undesirable changes (such as softening and degradation) to teeth and restorative materials $[2,6]$. The alterations reported thus far represent changes in the surface morphology, roughness, hardness, marginal microleakage and color of restorative materials [5-13]. Indeed, some studies reported negative effects of bleaching agents on chemical and physical properties of restorative materials [2,4-13], while others found only slight changes, or no significant alterations [14-19]. Possible negative effects of bleaching agents on restorative materials are particularly relevant in clinical cases that have a restorative material for extended period, especially in areas that are not recommended to be replaced [1-3].

Currently, feldspathic porcelain (ceramic) occupies an outstanding position as a restorative material due to its optical properties mimicking natural teeth, high physicalmechanical durability, chemical stability and biocompatibility with adjacent tissues, as well as a low biofilm adherence index [20-23]. Thus, ceramic fulfils aesthetic, biological, mechanical and functional requirements, and is widely used in the fields of dentistry and prosthetics [16]. Despite its high structural stability, ceramic can be degraded (albeit inefficiently) by agents in the oral environment, food, drink and cleaning products (such as mouthwash), which may lead to filling deterioration, and create the need for restoration replacement [18].

Considering all the above mentioned, our focus was to evaluate whether two widely used tooth whitening gels Opalescence (15\% carbamide peroxide) and Opalescence Xtra Boost (38\% hydrogen peroxide) alters the surface roughness and microhardness of dental feldspathic ceramic (IPS In Line, from Ivoclar-Vivadent).

\section{METHODS}

\section{Specimen preparation}

Forty-eight feldspathic porcelain IPS InLine (Ivoclair Vivadent, São Paulo, Brazil) discs (16/group) were prepared for use in this study. To produce porcelain discs, a porcelain and sculpting liquid mixture was placed into a mold (made from a C-silicone laboratory putty (Zetalabor - Zhermack SpA, Via Bovazecchino, Badia Polesine, Italy) and allowed to dry. Then, discs were removed from molds, placed on a sagger tray, and fired in a porcelain oven (GramCeram LCD; GDS equipamentos e controles Ltda, São Paulo, SP, Brasil), according to the manufacturer's recommendations. Discs were trimmed on both sides with a diamond bur (717 G Series 4, KG Sorensen, São Paulo, SP Brazil), using a straight handpiece (to remove irregularities and create a flat surface), and then fired again in a porcelain oven, to obtain an auto-glazed surface. Discs were stored in deionized water at room temperature for 48 hours before treatments.

\section{Restorative and bleaching materials}

The following commercial dental products were used in this study: the feldspathic porcelain IPS InLine (Ivoclair Vivadent, São Paulo, Brazil), and the bleaching gels Opalescence (15\% Carbamide peroxide, $\mathrm{pH}=6.5$ ) and Opalescence Xtra Boost (38\% hydrogen peroxide, $\mathrm{pH}=6.5)$, both from Ultradent (Utah, USA).

\section{Bleaching treatments}

Discs were divided into 3 groups (16/group) and subjected to one of following treatments for 14 days: 
a) untreated discs (UN) were kept in deionized water, which was changed daily;

b) discs treated with Opalescence (15\% Carbamide peroxide, $\mathrm{pH}=6.5$; Ultradent [Utah, USA]) for 6 hours/day (OPA);

c) discs treated with Opalescence Xtra Boost (38\% hydrogen peroxide, $\mathrm{pH}=6.5$; [Ultradent (Utah, USA]) for 1 h/day (OPAXB).

Discs were immersed daily in bleaching gels (or water) and left indisturbed for the entire duration of daily treatment periods. After each daily treatment, specimens were washed in running water and then measurements were made.

Surface roughness $(\mathrm{Ra})$ was analyzed using an SJ-410 surface roughness tester (Mitutoyo, China), under constant pressure, and with a cutoff value of $2.5 \mathrm{~mm}$.

Surface microhardness (Knoop, or KNP) measurements were performed with a HMV 2000 Knoop hardness tester (Shimadzu, Tokyo, Japan) which applied a $25 \mathrm{~g}$ load to each specimen, for $10 \mathrm{~s}$.

For both roughness and hardness, four measurements were performed at different positions on each specimen - at days 0 and 14 of treatment - and the mean value of the two measurements of each specimen was recorded.

Statistical analysis was performed using the paired t-test Student, at a confidence level of $95 \%$. The null hypotheses tested were: (1) Opalescence and/or Opalescence Xtra Boost alter the roughness of feldspathic porcelain; (2) Opalescence and/or Opalescence Xtra Boost alter the microhardness of feldspathic porcelain used in this study.

\section{RESULTS}

To mimic treatments performed in the clinic and at home, discs were treated with two different bleaching gels: for home use (Opalescence, 15\% carbamide peroxide), and for professional use (Opalescence Xtra Boost, 38\% hydrogen peroxide). Daily exposure periods were selected to mimic short or long-term treatments, used in office and at home, respectively.

Values of mean surface roughness and standard deviations (SD) for each combination of bleaching and restorative material are given in table 1 . In table 2 , values of mean microhardness and standard deviations (SD) for each combination of bleaching and restorative material.

Table 1. Effect of dental bleaching gels on the surface roughness (in Ra) of feldspathic porcelain.

\begin{tabular}{lcclll}
\hline & \multicolumn{2}{c}{ Initial } & & \multicolumn{2}{c}{14 days } \\
\cline { 2 - 3 } \cline { 5 - 6 } & Mean & SD & & Mean & SD \\
\hline Untreated & 0.500 & 0.128 & & 0.469 & 0.114 \\
$\begin{array}{l}\text { Opalescence } \\
\text { Opalescence }\end{array}$ & 0.537 & 0.228 & & 0.554 & 0.149 \\
\begin{tabular}{l} 
Xtra Boost \\
\hline
\end{tabular} & 0.664 & 0.075 & & 0.619 & 0.125 \\
\hline
\end{tabular}

Table 2. Effect of dental bleaching gels on the microhardness (KNP) of feldspathic porcelain.

\begin{tabular}{lcclcc}
\hline & \multicolumn{2}{c}{ Initial } & & \multicolumn{2}{c}{14 days } \\
\cline { 2 - 3 } \cline { 5 - 6 } \cline { 5 - 6 } & Mean & SD & & Mean & SD \\
\hline Untreated & 422.25 & 32.78 & & 439.85 & 62.12 \\
Opalescence & 435.75 & 87.33 & & 428.49 & 56.45 \\
$\begin{array}{l}\text { Opalescence } \\
\text { Xtra Boost }\end{array}$ & 499.87 & 114.36 & & 435.50 & 53.88 \\
\hline
\end{tabular}

In general, the action of bleaching agents resulted in a slight increase in surface roughness $(p<0.6199861)$ and a slight decrease in microhardness $(p<0.14286744)$. We did not detect statistically significant differences in surface roughness between specimens placed in different bleaching agents, compared with the untreated control (immersed in deionized water) ( $p=0.6199861)$ (table 3). Similarly, the evaluation of the microhardness did not show statistically significant differences between treatment with bleaching agents and the untreated control $(p=0.14286744)$ (table 3).

Table 3. Tukey test of surface roughness and microhardness of eldspathic porcelain. Comparisons between Opalescence and palescence Xtra Boost.

\begin{tabular}{lccccc}
\hline & \multicolumn{2}{c}{ Surface roughness } & & \multicolumn{2}{c}{ Surface microhardness } \\
\cline { 2 - 3 } \cline { 5 - 6 } \cline { 5 - 6 } Deadline & Mean & SD & & Mean & SD \\
Baseline & 0.57 & 0.17 & & 455.04 & 86.28 \\
P value & 0.55 & 0.14 & & 433.86 & 54.47 \\
\hline
\end{tabular}

\section{DISCUSSION}

Although bleaching agents are widely used for teeth bleaching, the effect of these agents on restorative materials 
remains controversial [1-6,17-25]. Possible alterations to the physical properties (such as microhardness, flexural strength, flexural modulus, and fracture toughness) of restorative materials are important aspects to consider when performing bleaching, since changes to these properties may influence the quality and durability of restorations [2,4-13].

In the present study, we examined the effects of an 'at-home' bleaching agent (Opalescence) and an 'in-office' bleaching agent (Opalescence Xtra Boost) on feldspathic porcelain, the preferred material used in dental restorations. The ceramic used in our study was reinforced with leucite and fluorapatite and is considered a 'glassceramic'. No statistically significant changes were observed in the surface roughness and microhardness of feldspathic porcelain after treatment with bleaching gels. These results confirm those of previous studies that reported no changes in either roughness or microhardness of feldspathic porcelain after treatment with bleaching gels $[12,13]$.

In contrast, previously studies have shown that porcelains might suffer significant roughening when treated with $10 \%$ carbamide peroxide $[7,26]$. Another study reported that feldspathic porcelain had a significantly rougher surface after 21 days of exposure to either $10 \%$ or $35 \%$ carbamide peroxide agents [11]. Possibly the differences reported are due to a removal of components from the porcelain matrix, as a function of continued peroxide application. This hypothesis arose because of a previous research showing that exposure to carbamide peroxide agents decreases the $\mathrm{SiO} 2$ and $\mathrm{K} 2 \mathrm{O} 2$ contents of the same type of feldspathic porcelain tested here $[23,27]$. An increase in roughness and a reduction in microhardness - due to organic matrix erosion - may expose weaknesses in restorations, and decrease their wear resistance [18].

\section{CONCLUSION}

Considering clinical conditions reported in this study, bleaching gels do not have a significant effect on key surface properties of feldspathic porcelain, resulting in a suitable clinical choice when patients have this porcelain treatments.

\section{Collaborators}

DCF SOUZA, experimental procedure and analysis and wrote the manuscript. LAC GONÇALVES, experimental procedure.
KCS GASQUE, data discussion, critical review, and translation of the manuscript. ABS MORETTI, data analysis and critical review. BF DA SILVA, experimental procedure and data discussion. RT MORETTI NETO, conceived and designed the idea, supervised data collection, and data discussion.

\section{REFERENCES}

1. Aattin $T$, Betke $H$, Schippan F, Wiegand A. Potential of fluoridated carbamide peroxide gels to support postbleaching enamel re-hardening. J Dent. 2007;35(9):755-759. http://dx.doi.org/10.1016/j.jdent.2007.06.005

2. Al-Ameedee AH, Ragabb HM, Osman E, Salameh Z. Evaluation effect of an in-office zoom bleaching gel agent on the surface texture of three contemporary restorative materials. Tanta Dent J. 2015;12(3):168-177. http://dx.doi.org/10.1016/j.tdj. 2015.05.005

3. Alqahtani MQ. Tooth-bleaching procedures and their controversial effects: A literature review. Saudi Dent J. 2014;26(2):33-46. http://dx.doi.org/10.1016/j.sdentj.2014.02. 002

4. Bahannan SA. Effects of different bleaching agent concentrations on surface roughness and microhardness of esthetic restorative materials. Saudi J Dent Res. 2015;6(2):124128. http://dx.doi.org/10.1016/j.sjdr.2015.01.002

5. Bailey SJ, Swift EJ. Effects of home bleaching products on composite resins. Quintessence Int. 1992;23(7):489-494.

6. Yu H, Zhang $\mathrm{CY}$, Cheng SL, Cheng H. Effects of bleaching agents on dental restorative materials: a review of the literature and recommendation to dental practitioners and researchers. J Dent Sci. 2015;10(4):345-351. http://dx.doi. org/10.1016/j.jds.2014.08.005

7. Butler CJ, Masri R, Driscoll CF, Thompson GA, Runyan DA, Anthony FJ. Effect of fluoride and $10 \%$ carbamide peroxide on the surface roughness of low-fusing and ultra low-fusing porcelain. J Prosthet Dent. 2004;92(2):179-183. http://dx.doi. org/10.1016/j.prosdent.2004.04.025

8. Hatanaka GR, Abi-Rached FO, Almeida-Junior AA, Cruz CAS. Effect of carbamide peroxide bleaching gel on composite resin flexural strength and microhardness. Braz Dent J. 2013;24(3):263-266. http://dx.doi.org/10.1590/0103-644020 1302155

9. Duschner $H$, Götz H, White DJ, Kozak KM, Zoladz JR. Effects of hydrogen peroxide Bleaching strip gels on dental restorative materials in vitro: Surface microhardness and surface morphology. J Clin Dent. 2004;15(4):105-111.

10. Malkondu Ö, Yurdagüven H, Say EC, Kazazoğlu E, Soyman M. Effect of bleaching on microhardness of esthetic restorative materials. Oper Dent. 2011;36(2):177-186. http://dx.doi. org/10.2341/10-078-I

11. Moraes RR, Marimon JL, Schneider LF, Correr Sobrinho L, Camacho GB, Bueno M. Carbamide peroxide bleaching agents: effects on surface roughness of enamel, composite and porcelain. Clin Oral Investig. 2006;10:23-28. http:// dx.doi.org/10.1007/s00784-005-0016-1 
12. Ourique ASM, Arrais CA, Cassoni A, Ota-Tsuzuki C, Rodrigues JA. Effects of Different Concentrations of Carbamide Peroxide and bleaching periods on the roughness of dental ceramic. Braz Oral Res. 2011;25(5):453-458. http://dx.doi. org/10.1590/\$18063242011000500013

13. Ourique ASM, Zeidan LC, Cassoni A, Arrais CAG, Rodrigues JA. Surface roughness evaluation of in vitro refinished dental ceramics followed by bleaching treatment. Braz Dent Sci. 2013;16(3):26-34. http://dx.doi.org/10.14295/bds.2013.v16i3. 886

14. Matis BA, Coachman MA, Eckert G. Review of the Effectiveness of Various Tooth Withening Systems. Oper Dent. 2009;34(2):230-235. http://dx.doi.org/10.2341/08-74

15. Schemehorn B, Gonzales-Cabezas C, Joiner A. A SEM evaluation of a $6 \%$ hydrogen peroxide tooth whitening gel on dental materials in vitro. J Dent. 2004;32(Suppl1):35-39. http://dx.doi.org/10.1016/j.jdent.2003.10.012

16. De A Silva MF, Davies RM, Stewart B, DeVizio W, Tonholo J, da Silva Júnior JG, Pretty IA. Effect of whitening gels on the surface roughness of restorative materials in situ. Dent Mater. 2006;22(10):919-924. http://dx.doi.org/10.1016/j. dental.2005.11.029

17. Torres CRG, Wiegand A, Sener B, Attin T. Influence of chemical activation of a $35 \%$ hydrogen peroxide bleaching gel in its penetration an efficacy-In vitro study. J Dent. 2010;38:838-846. http://dx.doi.org/10.1016/j.jdent.2010.07.002

18. Turker SB, Biskin T. Effect of three bleaching agents on the surface properties of three different esthetic restorative materials. J Prosthet Dent. 2003;89(5):466-473. http://dx.doi. org/10.1016/s0022-3913(03)00105-7

19. Vanderlei $A D$, Passos SP, Salazar-Marocho SM, Pereira SM, Vásquez VZ, Bottino MA. Effect of bleaching agent on dental ceramics roughness. Acta Odontol Latinoam. 2010;23(3):257-264.

20. Layton DM, Clarke MA. Systematic review and meta-analysis of the survival of feldspathic porcelain veneers over 5 and 10 years. Int J Prosth. 2012;25(6):590-603.
21. Morimoto S, Albanesi RB, Sesma N, Agra CM, Braga MM. Main clinical outcomes of feldspathic porcelain and glass-ceramic laminate veneers: a systematic review and meta-analysis of survival and complication rates. Int J Prosth. 2016;29(1):38-49. http://dx.doi.org/10.11607/ijp.4315

22. Morimoto S, Rebello de Sampaio FBW, Braga MM, Sesma N, Özcan M. Survival rate of resin and ceramic inlays, onlays, and overlays: a systematic review and meta-analysis. J Dent Res. 2016;95(9):985-994. https://doi.org/10.1177/00220345 16652848

23. Sailer I, Makarov NA, Thoma DS, Zwahlen M, Pjetursson BE. All-ceramic or metal-ceramic tooth-supported fixed dental prostheses (FDPs)? A systematic review of the survival and complication rates. Part I: Single crowns(SCs), Dent Mat. 2015;31(6):603-623. http://dx.doi.org/10.1016/j.dental.2015. 02.011

24. Matis BA, Coachman MA. Review of the effectiveness of various tooth withening systems. Oper Dent. 2009;34(2):230-235. http://dx.doi.org/10.2341/08-74

25. Schemehorn B, Gonzales-Cabezas C, Joiner A. A SEM evaluation of a $6 \%$ hydrogen peroxide tooth whitening gel on dental materials in vitro. J Dent. 2004;32(suppl.1):35-39. http://dx.doi.org/10.1016/j.jdent.2003.10.012

26. Vanderlei AD, Passos SP, Salazar-Marocho SM, Pereira SM, Vásquez VZ, Bottino MA. Effect of bleaching agent on dental ceramics roughness. Acta Odontol Latinoam. 2010;23(3):257-264.

27. Kaur S, Makkar S, Kumar R, Pasricha S, Gupta P. Comparative evaluation of surface properties of enamel and different esthetic restorative materials under erosive and abrasive challenges: an in vitro study. Indian J Dent. 2015;6(4):172-180. http://dx.doi.org/10.4103\%2F0975-962X.165047

Received on: 7/5/2019 Final version resubmitted on: 6/8/2019 Approved on: 10/9/2019 